\title{
Literature Review: Game Based Pedagogy in Accounting Education
}

\author{
Ganga Bhavani ${ }^{1}$, Anupam Mehta ${ }^{2} \&$ Suchi Dubey ${ }^{3}$ \\ ${ }^{1}$ Amity University, Dubai, UAE \\ ${ }^{2}$ Birmingham University, UK \\ ${ }^{3}$ Manipal Academy of Higher Education, Dubai, UAE \\ Correspondence: Ganga Bhavani, Assistant Professor, Amity University, Dubai, UAE.
}

Received: June 27, 2020

Accepted: August 17, 2020

Online Published: November 30, 2020

doi:10.5430/ijfr.v11n6p165

URL: https://doi.org/10.5430/ijfr.v11n6p165

\begin{abstract}
The main purpose of this study is to provide the comprehensive literature review in the nexus of accounting games (manual and digital). Students' expectation for learning concepts is rapidly changing and their concentration levels are decreasing drastically. Students are exposed to various levels of games and activities right from childhood and their expectation of games extended to the education as well. Now, it is the turn of educators to adopt the various concepts of teaching and learning in the mode of activities rather traditional method/s. The discipline of accounting is not an exception to this radical change. Accounting students wants to learn concepts with the help of games, activities either manual or digital. Some researchers developed and executed games in accounting education. Unfortunately, most of the games are not popular and predictable to the accounting educators. It may not be possible to an educator to invent a game for all the concepts all the time to present in the class. The current study explores all articles on Accounting games pedagogy (manual and digital) published in prominent $\mathrm{A}^{*}$, A and B category Accounting journals of ABDC (2019) list (53 Accounting Journals) during 15-year period i.e. from 2005-2019. Articles from these journals are categorized into five sections corresponding to traditional knowledge bases: (1) Curriculum and instruction (2) Instruction by content area (3) Educational Technology (4) Students (5) Faculty. We aim to support the Accounting educators to take a quick reference of our article to get an insight on available games before going to the class. We tried our best to present the details of games \& activities as much deeper as possible for the ready reference but in case educators look for more information, they can always refer the original published paper.
\end{abstract}

Keywords: accounting education, manual games, digital games, game based pedagogy, accounting educators

\section{Introduction}

The present millennial generation of students are technology-driven and expect to learn through technology than traditional models of teaching and learning. A game is a fun activity which challenges the students mentally (Kinzie and Joseph, 2008). Games encourage the student's inquiry which helps to engage the students constructively. The use of games in teaching and learning pedagogy, enhances the involvement and engagement of students (Carenys and Moya, 2016).

Game-based activities in teaching and learning have become very popular among school children and adolescents compared to university students (Tao, Cheng, \& Sun, 2009). Some disciplines in the university level, such as engineering, mathematics, computer science and languages have prevalent data base on game-based pedagogy compared to business management in general and accounting in particular. In the discipline of accounting very smaller number of topics and titles has been explored for game-based pedagogy. Even though accounting requires more practical approach and hands-on practice but hardly any presence of manual and digital game-based activities. Although the literature on game-based pedagogy is increasing (Annetta, Minogue, Holmes, \& Cheng, 2009) but still we lack in many disciplines including accounting.

The purpose of this review is to address comprehensive literature review in the nexus of Accounting games (manual and digital). Education needs to adapt the current trends and demands of students to enhance their learning capabilities and to derive better results. Our paper addresses the gap between what is expected by the students for fun learning and what is created and published by the educators and researchers focusing only on the discipline of 
Accounting Education. By presenting the results of literature from the past 15 years on accounting education games and activities, our goal is to motivate researchers to expand and focus on this area of research further.

The current study presents research method in the next section followed by analysis and discussion (two sections) and finally concludes with the conclusion and scope for future research.

\section{Research Method}

We explored all articles on Accounting games pedagogy (manual and digital) published in prominent $\mathrm{A}^{*}, \mathrm{~A}$ and $\mathrm{B}$ category Accounting journals of Australian Business Deans Council (ABDC), 2019 list (53 Accounting Journals, Annexure 1) ( Source: retrieved from webpage of ABDC) during 15-year period i.e. from 2005-2019. ABDC was developed by Australian Business Deans Council in 2007 to bring out the international journal quality list for business journals. The list was updated in year 2009, 2013, and 2016 and divides journals into 4 categories i.e. A*, A, $\mathrm{B}$ and $\mathrm{C}$ journals. There are a total of 1587 A*, A and B category journals in ABDC, 2019 list including all disciplines of Business Management and Commerce. We selected only 53 Accounting Journals in the categories from $\mathrm{A}^{*}$ to $\mathrm{B}$, by looking at the title of the journal. There may be other journals indexed in ABDC which has the scope of accounting but not mentioned in the title, we have not included such journals.

We used the key words as "Accounting Games in Higher Education, Manual Games in Accounting Curriculum, Digital Games in Accounting Curriculum, Activity Based Teaching and Learning in Accounting Pedagogy, Activity Based Teaching, Education Technology in Accounting Teaching, Curriculum and Instruction in Accounting using Activity/s, Active learning of Accounting, Educational Games, Active Engagement'. We were not satisfied with the results of articles through these key words used. So, we searched the list of 'Archives' in each selected journal within the specified period. For confirming the scope of the found papers to add in this review, we read the full paper/s by availing that paper either through the journal with paid or non- paid subscriptions and/or using Ebsco. We could able to identify only 10 articles and 1 case study exactly falling in the scope of current study.

The current study follows two sections in Analysis and Discussion. Section 1 presents 9 tabulations made from 10 articles and 1 case study we found. Followed by section 2 summarizes the found articles. These articles are categorized into five sections corresponding to traditional knowledge bases: (1) Curriculum and instruction (2) Instruction by content area (3) Educational Technology (4) Students (5) Faculty.

\section{Analysis and Discussion}

\section{Section 1: Tabulations}

The current study is covers 15 full years i.e. from 2004 to 2019. Table 1 depicts the data of each article and time period of publication. We found only 10 articles and case study published in the selected time period, in which 5 articles are in the period between 2004 to 2008 and the other 5 articles and case study in the period between 2014 to 2019. There are no articles published for the period 2009 to 2013. Table 2 presents the list Journals of the sample articles for the said time period. This shows the searched 10 articles plus one case study on accounting game-based pedagogy has been published in only 5 journals. Whereas in Table 3, articles, journals and specific year of publication is given. It's been exhibited that Journal 'Accounting Education: An International Journal' has been published 5 articles and the latest case study, 'play it again' in 2019. Followed by 'Accounting and Finance' two articles and 'Journal of Accounting Education' two articles, 'Behaviour Research in Accounting' one article got published.

Consistent with the prior literature we tried to classify articles into empirical, descriptive and case study based. Empirical articles are the ones based on data collection either through secondary or primary sources and arriving conclusions based on that. Whereas, descriptive articles are without statistical analysis and only describes and discusses the issues. Case studies are systematic process of research on an organisation, group, person/period for a specific period. Table 4 of current study presents article classification into empirical, descriptive or case study. Out of total 10 articles $(72.73 \%)$ we found in this study 8 (18.18\%) articles are empirical research based, 2 articles are descriptive based and one case study (9.09\%).

Table 5 depicts author/s count to type of article base (empirical, descriptive and case). Out of the total 8 articles in empirical base, 3 articles are published by one author, 1 article with two authors and the last 4 articles are published by 3 authors. Whereas out of 2 articles on descriptive base 1 article is published by one author alone and the other one with two authors. Case study has only one article.

Table 6 shows the analysis of the articles into five sections corresponding to traditional knowledge bases: (1) Curriculum and instruction (2) Instruction by content area (3) Educational Technology (4) Students (5) Faculty. In 
curriculum and instruction category only one descriptive based article got published in Accounting Research Journal. Shockingly, not even a single article in Instruction by content area, although this the most important criteria in accounting pedagogy. We found two empirical articles with use of technology which are published in the journals of 'Accounting and Finance' and 'Journal of Accounting Education'. The number of articles published on accounting game pedagogy are high in the journal of 'Accounting Education: An International Journal compared to the other journals of this study. Four empirical and one descriptive article on a total six articles published in this journal focuses on students. Whereas one empirical paper each got published in, 'Behaviroal Research in Accounting' and 'Accounting and Finance'. Faculty focused publications are not there in these journals for the selected time period.

Table 7 shows the data collection methods used in empirical articles. Articles published on educational technology followed survey-based techniques, students focused survey are two articles and course performance based one article out of the eight empirical articles found in this study. Table 8 depicts the analysis approach used in empirical articles. Regression technique is used in one paper (12.50\%), Tabulations has been used in 5 papers (62.50\%) and Analysis of variance is used in two papers (25\%).

Table 9 presents geographic location of sample used in empirical articles (total 8 articles). All the empirical papers of this study are coming from only three continents, USA \& Canada two articles students focused empirical survey based (25\%), Australia \& New Zealand four articles students and educational technology based (50\%) and Europe two papers education and survey based (25\%). Table 10 presents a brief description of each article we found in this study on Accounting game pedagogy with the respective author/s.

Table 1. Article and period of publication

\begin{tabular}{|c|c|c|c|}
\hline \multirow[b]{2}{*}{ Articles } & \multicolumn{3}{|c|}{ Period Covered } \\
\hline & $\begin{array}{l}2004- \\
2008\end{array}$ & $\begin{array}{l}2009- \\
2013\end{array}$ & $2014-$ \\
\hline Decision Aids and Experiential Learning & $\sqrt{ }$ & & \\
\hline $\begin{array}{l}\text { Integrating a virtual learning environment into a second-year accounting course: } \\
\text { determinants of overall student perception }\end{array}$ & $\checkmark$ & & \\
\hline Simulated financial dealing room: learning discovery and student accountability & $\checkmark$ & & \\
\hline $\begin{array}{l}\text { Facilitating creativity in management accounting: a computerized business } \\
\text { simulation }\end{array}$ & $\checkmark$ & & \\
\hline $\begin{array}{l}\text { Using computerized business simulations and spreadsheet models in accounting } \\
\text { education: a case study }\end{array}$ & $\checkmark$ & & \\
\hline $\begin{array}{l}\text { Game play in the learning environment: who wants to be an accountant? lawyer? } \\
\text { economist? }\end{array}$ & $\checkmark$ & & \\
\hline Digital game-based learning in accounting and business education & & & $\checkmark$ \\
\hline $\begin{array}{l}\text { Building a market simulation to teach business process analysis: effects of realism } \\
\text { on engaged learning }\end{array}$ & & & $\checkmark$ \\
\hline The future of 'serious games' in accounting education: A Delphi study & & & $\checkmark$ \\
\hline $\begin{array}{l}\text { Addressing the AICPA core competencies through the usage of the monopoly }{ }^{\mathrm{TM}} \\
\text { board game }\end{array}$ & & & $\checkmark$ \\
\hline $\begin{array}{l}\text { Play it again: how game-based learning improves flow in Accounting and } \\
\text { Marketing education }\end{array}$ & & & $\checkmark$ \\
\hline
\end{tabular}

Table 2. Journal and period of publication

\begin{tabular}{llll}
\hline & \multicolumn{2}{l}{ Period Covered } & \\
\hline Journals & $\mathbf{2 0 0 4 - 2 0 0 9}$ & $\mathbf{2 0 0 9}$ - 2013 & $\mathbf{2 0 1 4}$ - 2019 \\
Behavioural Research in Accounting & $\checkmark$ & \\
Accounting and Finance & $\checkmark$ & $\checkmark$ \\
Accounting Education : An International Journal & $\checkmark$ & $\checkmark$ \\
Journal of Accounting Education & & $\checkmark$ \\
Accounting Research Journal & & \\
\hline
\end{tabular}


Table 3. Journal and article publication with year

\begin{tabular}{|c|c|c|}
\hline Article & Journal & $\begin{array}{l}\text { Year of } \\
\text { Publication }\end{array}$ \\
\hline Decision Aids and Experiential Learning & $\begin{array}{l}\text { Behavioral Research in } \\
\text { Accounting }\end{array}$ & 2005 \\
\hline $\begin{array}{l}\text { Integrating a virtual learning environment into a second-year } \\
\text { accounting course: determinants of overall student perception }\end{array}$ & Accounting and Finance & 2008 \\
\hline $\begin{array}{l}\text { Simulated financial dealing room: learning discovery and student } \\
\text { accountability }\end{array}$ & Accounting and Finance & 2008 \\
\hline $\begin{array}{l}\text { Facilitating creativity in management accounting: a computerized } \\
\text { business simulation }\end{array}$ & $\begin{array}{l}\text { Accounting Education : } \\
\text { An International Journal }\end{array}$ & 2004 \\
\hline $\begin{array}{l}\text { Using computerized business simulations and spreadsheet models in } \\
\text { accounting education: a case study }\end{array}$ & $\begin{array}{l}\text { Accounting Education : } \\
\text { An International Journal }\end{array}$ & 2004 \\
\hline $\begin{array}{l}\text { Game play in the learning environment: who wants to be an } \\
\text { accountant? lawyer? economist? }\end{array}$ & $\begin{array}{l}\text { Accounting Education : } \\
\text { An International Journal }\end{array}$ & 2005 \\
\hline Digital game-based learning in accounting and business education & $\begin{array}{l}\text { Accounting Education : } \\
\text { An International Journal }\end{array}$ & 2016 \\
\hline $\begin{array}{l}\text { Building a market simulation to teach business process analysis: } \\
\text { effects of realism on engaged learning }\end{array}$ & $\begin{array}{l}\text { Accounting Education : } \\
\text { An International Journal }\end{array}$ & 2018 \\
\hline The future of 'serious games' in accounting education: A Delphi study & $\begin{array}{l}\text { Journal of Accounting } \\
\text { Education }\end{array}$ & 2019 \\
\hline $\begin{array}{l}\text { Addressing the AICPA core competencies through the usage of the } \\
\text { monopoly }{ }^{\mathrm{TM}} \text { board game }\end{array}$ & $\begin{array}{l}\text { Accounting Research } \\
\text { Journal }\end{array}$ & 2019 \\
\hline $\begin{array}{l}\text { Play it again: how game-based learning improves flow in Accounting } \\
\text { and Marketing education }\end{array}$ & $\begin{array}{l}\text { Accounting Education : } \\
\text { An International Journal }\end{array}$ & 2019 \\
\hline
\end{tabular}

Table 4. Article classification by journal

\begin{tabular}{llllll}
\hline & Articles summarized & & & \\
\hline & Empirical & Descriptive & Total & Cases & $\begin{array}{l}\text { Grand } \\
\text { Total }\end{array}$ \\
\hline & & & & & \\
Behavioral Research in Accounting & $\mathbf{1}$ & $\mathbf{0}$ & $\mathbf{1}$ & $\mathbf{0}$ & $\mathbf{1}$ \\
Accounting and Finance & 2 & 0 & $\mathbf{2}$ & 0 & $\mathbf{2}$ \\
Accounting Education : An International & 4 & 1 & $\mathbf{5}$ & 1 & $\mathbf{6}$ \\
Journal & 1 & 0 & $\mathbf{1}$ & 0 & $\mathbf{1}$ \\
Journal of Accounting Education & 0 & 1 & $\mathbf{1}$ & 0 & $\mathbf{1}$ \\
Accounting Research Journal & 8 & 2 & $\mathbf{1 0}$ & 1 & $\mathbf{1 1}$ \\
Total & $\mathbf{7 2 . 7 3 \%}$ & $\mathbf{1 8 . 1 8 \%}$ & $\mathbf{1 0 0 \%}$ & $\mathbf{9 . 0 9 \%}$ & $\mathbf{1 0 0 \%}$ \\
Percentage of Grand Total & & &
\end{tabular}

Table 5. Summary of author count by article type

\begin{tabular}{lllll}
\hline & \multicolumn{4}{l}{ Author Count Per Article } \\
\hline Article type & Total articles & $\mathbf{1}$ Author & 2 Authors & 3 Authors \\
\hline Empirical & 8 & 3 & 1 & 4 \\
Descriptive & 2 & 1 & 1 & 0 \\
Case & 1 & 1 & 0 & 0 \\
Total & $\mathbf{1 1}$ & $\mathbf{5}$ & $\mathbf{2}$ & $\mathbf{4}$ \\
Percentage of total & $\mathbf{1 0 0 \%}$ & $\mathbf{4 5 . 4 5 \%}$ & $\mathbf{1 8 . 1 8 \%}$ & $\mathbf{3 6 . 3 6 \%}$ \\
\hline
\end{tabular}


Table 6. Number of empirical (E) and descriptive (D) articles by section reference and subject area

\begin{tabular}{|c|c|c|c|c|c|c|c|c|c|c|c|c|}
\hline \multirow[t]{3}{*}{ Journal } & \multicolumn{12}{|c|}{ Section reference and subject area. } \\
\hline & \multicolumn{2}{|c|}{$\begin{array}{l}\text { Curriculum } \\
\text { and } \\
\text { instruction }\end{array}$} & \multicolumn{2}{|c|}{$\begin{array}{l}\text { Instruction by } \\
\text { content area }\end{array}$} & \multicolumn{2}{|c|}{$\begin{array}{l}\text { Educational } \\
\text { technology }\end{array}$} & \multicolumn{2}{|c|}{ Students } & \multicolumn{2}{|c|}{ Faculty } & \multicolumn{2}{|c|}{$\begin{array}{l}\text { Total } \\
\text { summarized } \\
\text { articles }\end{array}$} \\
\hline & $\mathbf{E}$ & D & $\mathbf{E}$ & D & $\mathbf{E}$ & D & $\mathbf{E}$ & D & $\mathbf{E}$ & $\mathbf{D}$ & $\mathbf{E}$ & D \\
\hline $\begin{array}{l}\text { Behavioral } \\
\text { Research in } \\
\text { Accounting }\end{array}$ & 0 & 0 & 0 & 0 & 0 & 0 & 1 & 0 & 0 & 0 & 1 & 0 \\
\hline $\begin{array}{l}\text { Accounting and } \\
\text { Finance }\end{array}$ & 0 & 0 & 0 & 0 & 1 & 0 & 1 & 0 & 0 & 0 & 2 & 0 \\
\hline $\begin{array}{l}\text { Accounting } \\
\text { Education : An } \\
\text { International } \\
\text { Journal }\end{array}$ & 0 & 0 & 0 & 0 & 0 & 0 & 4 & 1 & 0 & 0 & 4 & 1 \\
\hline $\begin{array}{l}\text { Journal of } \\
\text { Accounting } \\
\text { Education }\end{array}$ & 0 & 0 & 0 & 0 & 1 & 0 & 0 & 0 & 0 & 0 & 1 & 0 \\
\hline $\begin{array}{l}\text { Accounting } \\
\text { Research Journal }\end{array}$ & 0 & 1 & 0 & 0 & 0 & 0 & 0 & 0 & 0 & 0 & 0 & 1 \\
\hline Total by section & $\mathbf{0}$ & 1 & $\mathbf{0}$ & $\mathbf{0}$ & 2 & $\mathbf{0}$ & 6 & 1 & $\mathbf{0}$ & $\mathbf{0}$ & 8 & 2 \\
\hline & & 1 & & 0 & & 2 & & 7 & & $\mathbf{0}$ & & 10 \\
\hline $\begin{array}{l}\text { Percentage of } \\
\text { total }\end{array}$ & & $10 \%$ & & $0 \%$ & & $20 \%$ & & $70 \%$ & & $0 \%$ & & $100 \%$ \\
\hline
\end{tabular}

Table 7. Data collection method used in empirical articles (by frequency count)

\begin{tabular}{|c|c|c|c|c|c|c|c|}
\hline $\begin{array}{l}\text { Section reference } \\
\text { and subject area }\end{array}$ & Survey & $\begin{array}{l}\text { Course } \\
\text { Performanc } \\
\text { e }\end{array}$ & $\begin{array}{l}\text { Publishe } \\
\text { d source }\end{array}$ & $\begin{array}{l}\text { Quasi-experimen } \\
\mathbf{t}\end{array}$ & $\begin{array}{l}\text { Intervie } \\
\mathbf{w}\end{array}$ & $\begin{array}{l}\text { Experimen } \\
\text { t }\end{array}$ & Total \\
\hline $\begin{array}{l}\text { Curriculum and } \\
\text { instruction }\end{array}$ & 0 & 0 & 0 & 0 & 0 & 0 & $\mathbf{0}$ \\
\hline $\begin{array}{l}\text { Instruction by } \\
\text { content area }\end{array}$ & 0 & 0 & 0 & 0 & 0 & 0 & 0 \\
\hline $\begin{array}{l}\text { Educational } \\
\text { technology }\end{array}$ & 2 & 0 & 0 & 0 & 0 & 0 & 2 \\
\hline Students & 5 & 1 & 0 & 0 & 0 & 0 & 6 \\
\hline Faculty & 0 & 0 & 0 & 0 & 0 & 0 & $\mathbf{0}$ \\
\hline $\begin{array}{l}\text { Total summarized } \\
\text { articles }\end{array}$ & 7 & 1 & 0 & 0 & $\mathbf{0}$ & 0 & 8 \\
\hline $\begin{array}{l}\text { Percentage of } \\
\text { total }\end{array}$ & $\begin{array}{l}87.50 \\
\%\end{array}$ & $12.50 \%$ & $0 \%$ & $0 \%$ & $0 \%$ & $0 \%$ & $\begin{array}{l}100 \\
\%\end{array}$ \\
\hline
\end{tabular}

Table 8. Analysis approach used in empirical articles (by frequency count)

\begin{tabular}{|c|c|c|c|c|c|c|}
\hline $\begin{array}{l}\text { Section reference and } \\
\text { subject area }\end{array}$ & Regression & $\begin{array}{l}\text { Differences-i } \\
\text { n-means }\end{array}$ & Tabulation & $\begin{array}{l}\text { Analysis } \\
\text { of } \\
\text { variance }\end{array}$ & $\begin{array}{l}\text { Path } \\
\text { Analysis }\end{array}$ & Total \\
\hline Curriculum and instruction & 0 & 0 & 0 & 0 & 0 & $\mathbf{0}$ \\
\hline Instruction by content area & 0 & 0 & 0 & 0 & 0 & $\mathbf{0}$ \\
\hline
\end{tabular}




\begin{tabular}{lllllll} 
Educational technology & 0 & 0 & 2 & 0 & 0 & $\mathbf{2}$ \\
Students & 1 & 0 & 3 & 2 & 0 & $\mathbf{6}$ \\
Faculty & 0 & 0 & 0 & 0 & 0 & $\mathbf{0}$ \\
Total summarized articles & $\mathbf{1}$ & $\mathbf{0}$ & $\mathbf{5}$ & $\mathbf{2}$ & $\mathbf{0}$ & $\mathbf{8}$ \\
Percentage of total & $\mathbf{1 2 . 5 0 \%}$ & $\mathbf{0 \%}$ & $\mathbf{6 2 . 5 0 \%}$ & $\mathbf{2 5 \%}$ & $\mathbf{0 \%}$ & $\mathbf{1 0 0}$ \\
& & & & & & $\mathbf{\%}$ \\
\hline
\end{tabular}

Table 9. Geographic location of sample used in empirical articles (by frequency count)

\begin{tabular}{lllll}
\hline Section reference and subject area & US and Canada & $\begin{array}{l}\text { Australia and New } \\
\text { Zealand }\end{array}$ & Europe & Total \\
\hline Curriculum and instruction & 0 & 0 & 0 & 0 \\
Instruction by content area & 0 & 0 & 0 & 0 \\
Educational technology & 0 & 1 & 1 & 2 \\
Students & 2 & 3 & 1 & 6 \\
Faculty & 0 & 0 & 0 & 0 \\
Total summarized articles & $\mathbf{2}$ & $\mathbf{4}$ & $\mathbf{2}$ & $\mathbf{8}$ \\
Percentage of total & $\mathbf{2 5 \%}$ & $\mathbf{5 0 \%}$ & $\mathbf{2 5 \%}$ & $\mathbf{1 0 0 \%}$ \\
\hline
\end{tabular}

Table 10. Overview of curriculum and instruction articles

\begin{tabular}{|c|c|c|}
\hline Authors & Type & Topic \\
\hline Rose, J. M. (2005) & $\mathrm{E}$ & Effect of Tax decision aid on knowledge acquisition of accounting students \\
\hline Wynder, M. (2004) & $\mathrm{E}$ & $\begin{array}{l}\text { Development and use of a computerized business simulation in a second year } \\
\text { management accounting course }\end{array}$ \\
\hline $\begin{array}{l}\text { Mceacharn, M. } \\
\text { (2005) }\end{array}$ & $\mathrm{E}$ & $\begin{array}{l}\text { Paper describes a computer-based game that was originally developed to } \\
\text { enhance the learning environment in a traditional auditing course }\end{array}$ \\
\hline Wells et al. (2008) & $\mathrm{E}$ & Student usage and perceptions of the Virtual Learning Environment \\
\hline $\begin{array}{l}\text { Carenys and Moya } \\
(2016)\end{array}$ & $\mathrm{D}$ & $\begin{array}{l}\text { This article presents a review of the accounting and business literature on } \\
\text { digital game-based learning (DGBL). }\end{array}$ \\
\hline $\begin{array}{l}\text { Peng and Abdullah } \\
\text { (2018) }\end{array}$ & $\mathrm{E}$ & $\begin{array}{l}\text { This study examines the success of using different simulation platforms in } \\
\text { creating a market simulation to teach business processes in the accounting } \\
\text { information systems course. }\end{array}$ \\
\hline Silva, et. al. (2019) & $\mathrm{E}$ & $\begin{array}{l}\text { The article provides an understanding of DGBL(Digital Game Based } \\
\text { Learning) using theoretical and empirical research questions in the accounting } \\
\text { discipline. }\end{array}$ \\
\hline $\begin{array}{l}\text { Lambert et al. } \\
(2008)\end{array}$ & $\mathrm{E}$ & Effectiveness of a simulated treasury dealing room for teaching and learning \\
\hline $\begin{array}{l}\text { Calabora et al. } \\
(2019)\end{array}$ & $\mathrm{E}$ & $\begin{array}{l}\text { Accounting academics perceptions of the usefulness and the potential barriers } \\
\text { to implementing Serious Games in the classroom }\end{array}$ \\
\hline Mousa, R. (2019) & $\mathrm{D}$ & $\begin{array}{l}\text { Learning outcomes of students of introductory financial accounting course } \\
\text { through their experience of playing the Monopoly TM board game }\end{array}$ \\
\hline
\end{tabular}

\section{Section 2: Paper Reviews}

2(a) Curriculum and Instruction: One paper

Title: 'Addressing the AICPA core competencies through the usage of the monopoly ${ }^{\mathrm{TM}}$ board game' by Rania Mousa.

Mousa, R. (2019) descriptively examined the learning outcome of students enrolled in financial accounting course by analysing their experience of playing Monopoly ${ }^{\mathrm{TM}}$ board game. Also mapping the individual's competency which 
are addressed in AICPA Core Competency Framework. There are broadly 3 categories of competencies these are functional, personal and broad business perspective. Monopoly ${ }^{\mathrm{TM}}$ board game provides basic understanding of business activities in a hypothetical real estate marketplace. Through this, students learn to analyse and report financial information and prepare financial statements.

A longitudinal qualitative analysis was done. To analyse author used content analysis of the learning outcome of 550 students of US university. Analysed data was again checked to find potential gaps then gap analysis was performed. Study shows that there is a connection between the learning outcome of the game and the competencies mentioned in AICPA Framework. It shows that the game is enjoyable, and it also develops the excel skills of the students along with providing practical application of accounting principles.

2(b) Instruction by Content Area: Did not find any papers in this area.

\section{2@ Educational Technology: Two papers}

2 (c) (i). Title: Integrating a virtual learning environment into a second-year accounting course: determinants of overall student perception by Paul Wells, Paul de Lange, Peter Fieger.

Wells et al. (2008) surveyed 206 students to identify student's usage and perception about Virtual Learning Environment (VLE). To better prepare current accounting students with the necessary and important skills there is growing focus on making students independent learners. This can be achieved using student centred programs and strategies like learning programs that are self-paced, group work or projects, creative use of technology in classes and encouraging students to participate actively in the learning process. Thus, to facilitate learning process adoption of technology is required. In this study regression was done on independent variables and overall perception of students on VLEs. Their perception of overall usefulness of VLE and VLE resource was measured by a survey. The survey instrument used was adapted with minor modification from De Lange et al. (2003) study which was taken from his previous study Suwardy and de Lange (1998).

Results showed that the use of Virtual Learning Environment (VLE) was a rewarding experience for the students and its usage and integration into learning process aided and enhanced student learning. Using VLEs the faculty became more accessible and approachable to the students and there was increase in the level of consensus for their introduction and usage in other courses as well.

2 ( ) (ii). Title: The future of 'serious games' in accounting education: A Delphi study by Mari Sol Calabora, Araceli Moraa, Soledad Moyab

Calabora et al. (2019) studied the perception of academics in accounting profession about the usefulness and various barriers that may arise in implementing serious game like simulation games in the classrooms. Use of serious games (SGs) is very minimal in educational universities, even though many researches show their usefulness. Lecturers are the main source for the introduction of Serious Games (SGs) in classrooms although they are also identified as the main barrier. Through analysing the lecturer's perspective, the aim is to explain the reason for limited use of SGs in accounting profession despite their advantages.

For this study Platform War Simulation (PWS) by Massachusetts Institute of Technology was used. Game is based on Sony decision to launch PlayStation 3 and the roles which were given to the players is of game producers like Sony, Microsoft, Nintendo. Players need to make various business decisions to maximise their firms' value. PWS Business game was used because in this simulation the most important source for making various decisions at managerial level was accounting information. To analyse the data Delphi method was used. In Delphi method various experts are asked to rate the different questions on a 5-point Likert scale. Along with this, experts were given the opportunity to explain their viewpoints. Advantage of this method is that it allows two-way communication between the respondent and the interviewer which is not possible in other type of data collection.

Results showed that panellist believed that the interface was pleasant, game allowed students to practice decision making and it also reflect real world. But there was no general agreement between the lecturers on the objective and the learning aims of the game. Most of the lecturers who were part of the panel did not believe in the simulation's suitability in various accounting courses. Although accounting was the key part of the simulation game, but it was not used as the technique to learn accounting but was used only in decision making process. Accounting is taught in classrooms as a technique not as data for decision making and thus it is not connected with various fields of study like general business, finance, investing in the classrooms. This has resulted in decrease in the level of enthusiasm of the students. 
2(d) Students: Seven published papers

2(d) (i) Title: Decision Aids and Experiential Learning by Jacob M. Rose.

Rose, J. M. (2005) observed 194 students of accounting information system course to measure what affect does a decision aid based on tax decisions has on the acquisition of knowledge by the students based on their perceived aptitude for tax and interest in taxation as a career. To measure the perceived aptitude and interest research employs career choice as a basis. Only students having no prior tax knowledge could participate.

There were 5 stages in the process: a pre-test phase, a general ability measurement phase, a knowledge acquisition phase, a distracter phase, and a test phase. Students for experiment were distributed in 3 treatments. Students first task was to complete a knowledge test after that they were required to solve a set of GRE questions and then at last, they were asked to solve three practice problems. Participants in the first group did questions without aid and rest received computer-based decision aid. At last all participants completed another test without decision aid (tax calculation instruction). After observing tabulation and correlation was done.

Result showed that students who had more perceived aptitude and interest in tax acquire more knowledge during the manual task of solving questions as compared to students with less interest and aptitude for taxation as a subject. In cases where decision aids imposed a high level of cognitive load on tax career participants resulted in students acquiring more tax knowledge than students who were not interested in tax as a career. On the other hand when decision aid reduced the cognitive burdens, learning rates of non-tax career participants were similar to the level of learning in unaided environment. Prior studies showed that decision aids resulted in reduced rate of knowledge acquisition and learning relative to manual environment because of the reduced efforts but on the contrary this study shows that learning in both the cases that is with and without aid can produce equivalent results.

2 (d) (ii). Title: Simulated financial dealing room: learning discovery and student accountability by Rod Lambert, Kevin Tant, John Watson.

Lambert et al. (2008) surveyed 43 business degree students in pre-test and 39 in post-test survey to measure the effectiveness and efficiency of simulation of a treasury dealing room for the teaching purpose and learning of the students. For a business course focus should be on practical application of knowledge and theories and to achieve this focus should be on learning through case studies and by Business games. The Treasury dealing room which was used in this study is one such games which was developed by Monash University. This simulation allows the management of the investment positions in the real time, through its usage the user can act as a market trader and apply the knowledge and various theories that they have learned in the classroom.

The use of simulation helps students in improving their motivation and it also improves their learning skills of various strategies by the way of implementing in real-like situation which is reached by processing deep level if learning. It helps them see the relevance of the theories that they have learned. Research instrument used presurvey and postsurvey of student's perception measured largely on a 5-point Likert scale. Results showed that students agree that they learned more tutorial/simulation than from lectures. Learning in the groups was more effective than solo learning. The level of overall satisfaction achieved through the dealing room was more and expectations was fully met. Also, student's ability to carefully monitor and analyse the effectiveness in their learning process is improved.

2 (d) (iii). Title: Building A Market Simulation to Teach Business Process Analysis: Effects of Realism on Engaged Learning by Jacob Peng and Ira Abdullah.

This paper examines (Peng and Abdullah 2017), the use of simulation processes in teaching accounting and uses simulation process to link the knowledge gained in class with practical applications. The paper tries to explain this through different learning simulation platforms. The paper describes creating a field experiment using 3 different simulation platforms - online virtual world simulation, online bulletin board simulation, and face-to-face platform. For the online virtual world simulation, the authors have used Second Life (SL) as their primary simulation platform which is used widely in the accounting education field. The second simulation platform used in the online bulletin board simulation is the Learning Management System (Blackboard's) threaded discussion. To maintain a base line for comparison, effect of face-to-face class learning simulation was also tested.

The sample size for this experiment was of 72 students, in which the effect of these simulations on learning was compared using 3 different simulation platforms. Results show that if students think that teaching through simulations can have an impact on the learning process, and those students who have some prerequisite knowledge of computers, have more positive outcome. Further analysis shows that the simulation is particularly effective in an online class setting. The contribution of this paper is to link how simulations can have an impact on the learning process. 
2(d) (iv). Title: Digital Game-Based Learning in Accounting and Business Education by Jordi Carenysa and Soledad Moyab.

This article reviews (Carenys and Moya,2016) the effects of digital game-based learning (DGBL) on accounting and businesses. The article has categorised the effectiveness and practical use of Digital Game-Based Learning (DGBL) into 3 categories.

In the first category, the game is evaluated for education purpose. Second category presents appropriate ness for DGBL deployment based on conclusions from the research. Finally, the paper talks about the types of learning outcomes which can be expected from these digital games, and how these outcomes can be evaluated. This article also provides researchers interested in DGBL with a set of interesting questions, answering which can help educators to better understand the use of DGBL.

2(d) (v). Title: Facilitating Creativity in Management Accounting: A Computerized Business Simulation by Monte Wynder.

The focus of this paper by Wynder (2004) is on the development aspects of computerized business simulations and how it is used for a second-year management accounting course. This paper identifies various key factors and features of the simulation process which can help to facilitate creativity in decision making. The simulation is then evaluated on the basis feedbacks from the students. The platform used for this business simulation exercise is MyMuse - it is a computerised business simulation. MyMuse is a simulation which will help students to successfully link and apply theoretical knowledge of accounting to a realistic scenario. The simulation identifies various complexities that exist in a business environment and to provide a holistic exposure to the students for improved learning experience which can be easily relate to the real world.

The computer simulation is an innovative and a fresh interface, activity-based teaching and learning pedagogy as compared to the traditional pen and paper format, to help the students to think on the spot and improve their creativity. This paper discusses the various steps used to implement the business simulation and then through feedback from students and evaluation of their results.

2 (e) (vi). Title: Game Play in the Learning Environment: Who Wants To Be An Accounting? Lawyer? Economist? By Michelle McEacharn

This paper describes the use of a computer-based game, "Who Wants To Be" (WWTB) that would enhance the learning experience of an auditing course. The game requires a student to answer a series of questions. The students are provided with lifelines like $-50 / 50$ lifeline, ask the audience lifeline, ask your team lifeline. After analysing the examination scores of those students who took a part in the game, it was found that the game has proven to be an effective learning tool for the auditing course.

The paper converse in detail about the functioning of the game, how to play it and the rules of the game. The paper evaluates the game's effectiveness based on evidence gathered from data through the results of final exams. The concept of mean is used to evaluate the evidence and compare the effectiveness of the game. The mean scores are used of 2 different time periods for comparison, first for 3 years before the use of the game and second for 3 years after the use of the game.

2(d) (vii). Play it Again: How Game-Based Learning improves flow in Accounting and Marketing Education by Rui Silva, Ricardo Rodrigues \& Carmem Leal

This article by Silva, Rodrigues \& Leal (2019) studies how digital games (educational) can have an impact on the performance of students attending an undergraduate course in Portuguese on Accounting and Marketing for the first time. This game is based on the characteristics of - Concentration, Clarity, Feedback, Challenge, Autonomy, Social Interaction, and Perceived Learning. A model using a structured flow was implemented to understand how these characteristics were impacting the learning flow of students, who used the games for learning and educational purpose. After the game was introduced in the course structure, the motivation and interest levels of the students showed a positive response which meant that games could be the next innovation needed to improve the learning process. This article employs a concept of flow theory, which means that the state of mind of a person can be characterised using factors like level of focus and interest which will relate to a high level of pleasure. Finally, this game is useful to understand whether the accounting and management games are effective tools to improve the learning process. 


\section{2(e) Faculty: (No papers)}

\section{Case Study}

Title: Using Computerized Business Simulations and Spreadsheet Models in Accounting Education: A Case Study by Neil Marriott (2004).

Students are motivated to learn accounting not because they like it or because they are good at it, but because they seek some future benefits out of learning accounting. Also, sometimes students lack experience because of which it becomes difficult for them to link the theoretical concepts learned by them in classes with the practical applications of those concepts. This case study by Marriott (2004) addresses the fact that with the help of computer simulation, accounting professionals and educators can impart better theoretical as well as practical knowledge to their students. The paper is provides critic view on computer simulation games arguing that the simulations games are less focused towards theoretical concepts and more focused towards learning from experience. The computerised simulation involves students using spreadsheet models for an undergraduate course at a UK University.

Many times, students prefer a more traditional approach when it comes to learning, however computer simulation can prove to be useful to gain virtual learning experience. Thus importantly, this paper highlights the benefits of computer simulation and how it can be used to give the students exposure of the real-world variables.

\section{Conclusion}

In reviewing the published accounting education research, we observed that the least focus has been paid by the educators and researchers on games and activity-based learning in accounting (manual \& digital). Only ten articles and one case study has been published in the prominent $53 \mathrm{ABDC}$ indexed journals for the period of 15 years is shocking. This research alarming the educators who is ignoring the millennial students' mind-set.

As apparent by the literature reviewed, the state of accounting education research in exploring game-based pedagogy is inactive and dull. This highlights the need for accounting educators to build upon learner-oriented teaching and learning areas. The articles reviewed $(10+1)$ have contributed new ideas and became successful in implementing curriculum and instruction ( 2 papers) and students (7 papers descriptive and empirical papers). By giving the in-depth review of literature in this study in section 2, we aim to support the Accounting educators to take a quick reference of our article to get an insight on available games before going to the class.

As found in the literature on simulation (virtual video games), we tried to explore the area of simulations as well. Educational community is in stipulation of virtual games and simulations to enhance the student performance, engagement and learning motivation (Vlachopoulos \& Makri, 2017). However, simulation studies are not new to teaching community and simulations are in teaching pedagogy practice from 1960s. Cotton, Ahmadi, \& Esselborn, (1997) through their study suggest that the simulation game generates lively faculty discussion and derives critical thinking outcomes from an existing valued learning strategy. We quickly explored the simulations developed by the most famous universities in the higher education Harvard University and MIT Sloan School of Management, United States of America (USA), regrettably not on accounting. Future research on this can be expanded to other leading indexes such as Association of Business Schools (ABS) and Scopus.

\section{References}

ABDC: Australian Business Deans Council. Retrieved from https://abdc.edu.au/

Annetta, L., Minogue, J., Holmes, S., \& Cheng, M. (2009). Investigating the impact of video games on high school student's engagement and learning about genetics. Computers \& Education, 53, 74-85.

Calabor, M. S., Mora, A., \& Moya, S. (2019). The future of "serious games" in accounting education: A Delphi study. Journal of Accounting Education, 46, 43-52. https://doi.org/10.1016/j.jaccedu.2018.12.004

Carenys, J., \& Moya, S. (2016). Digital game-based learning in accounting and business education. Accounting Education, 25(6), 598-651. https://doi.org/10.1080/09639284.2016.1241951

Carenys, J., Moya, S., \& Perramon, J. (2017). Is it worth it to consider videogames in accounting education? A comparison of a simulation and a videogame in attributes, motivation and learning outcomes. Revista de Contabilidad-Spanish Accounting Review, 20(2), 118-130. https://doi.org/10.1016/j.rcsar.2016.07.003

Kinzie, M. B., \& Joseph, D. R. D. (2008). Gender differences in game activity preferences of middle school children: Implications for educational game design. Educational Technology Research and Development, 56(5-6), 643-663. https://doi.org/10.1007/s11423-007-9076-z 
Lambert, R., Tant, K., \& Watson, J. (2008). Simulated financial dealing room: learning discovery and student accountability. Accounting \& Finance, 48(3), 461-474. https://doi.org/10.1111/j.1467-629x.2008.00274.x

Marriott, N. (2004). Using computerized business simulations and spreadsheet models in accounting education: a case study. Accounting Education, 13(sup1), 55-70. https://doi.org/10.1080/0963928042000310797

McEacharn, M. (2005). Game play in the learning environment: who wants to be an accountant? lawyer? economist?. Accounting Education, 14(1), 95-101. https://doi.org/10.1080/0963928042000287956

Mousa, R. (2019). Addressing the AICPA Core Competencies through the Usage of the Monopoly TM Board Game. Accounting Research Journal. https://doi.org/10.1108/arj-01-2017-0030.

Peng, J., \& Abdullah, I. (2017). Building a market simulation to teach business process analysis: effects of realism on engaged learning. Accounting Education, 27(2), 208-222. https://doi.org/10.1080/09639284.2017.1407248

Rose, J. M. (2005). Decision Aids and Experiential Learning. Behavioral Research in Accounting, 17(1), 175-189. https://doi.org/10.2308/bria.2005.17.1.175

Silva, R., Rodrigues, R., \& Leal, C. (2019). Play it again: how game-based learning improves flow in Accounting and Marketing education. Accounting Education, 28(5), 484-507. https://doi.org/10.1080/09639284.2019.1647859

Tao, Y.-H., Cheng, C.-J., \& Sun, S.-Y. (2009). What influences college students to continue using business simulation games? The Taiwan experience. Computers \& Education, 53, 929-939.

Wells, P., de Lange, P., \& Fieger, P. (2008). Integrating a virtual learning environment into a second-year accounting course: determinants of overall student perception. Accounting \& Finance, 48(3), 503-518. https://doi.org/10.1111/j.1467-629x.2007.00249.x

Wynder, M. (2004). Facilitating creativity in management accounting: a computerized business simulation. Accounting Education, 13(2), 231-250. https://doi.org/10.1080/09639280410001676639

\section{Appendix A}

List of Journals Used in the Current Study

\begin{tabular}{|c|c|c|c|}
\hline 1 & Accounting, Organizations and Society & Elsevier & $\mathrm{A}^{*}$ \\
\hline 2 & Contemporary Accounting Research & John Wiley \& Sons, Inc. & $\mathrm{A}^{*}$ \\
\hline 3 & Journal of Accounting and Economics & Elsevier & $A^{*}$ \\
\hline 4 & Journal of Accounting Research & John Wiley \& Sons, Inc. & $A^{*}$ \\
\hline 5 & Management Accounting Research & Elsevier & $A^{*}$ \\
\hline 6 & Review of Accounting Studies & Springer International Publishing & $A^{*}$ \\
\hline 7 & The Accounting Review & American Accounting Association & $A^{*}$ \\
\hline 8 & The European Accounting Review & Taylor \& Francis Online & $A^{*}$ \\
\hline 9 & $\begin{array}{l}\text { Abacus: a journal of accounting, finance and business } \\
\text { studies }\end{array}$ & John Wiley \& Sons, Inc. & A \\
\hline 10 & Accounting and Business Research & Taylor \& Francis Online & A \\
\hline 11 & Accounting and Finance & John Wiley \& Sons, Inc. & A \\
\hline 12 & Accounting Auditing and Accountability Journal & & A \\
\hline 13 & Accounting Horizons & American Accounting Association & A \\
\hline 14 & Behavioral Research in Accounting & American Accounting Association & A \\
\hline 15 & British Accounting Review & Elsevier & A \\
\hline 16 & Critical Perspectives on Accounting & Elsevier & A \\
\hline 17 & International Journal of Accounting Information Systems & Elsevier & A \\
\hline 18 & Journal of Accounting and Public Policy & Elsevier & A \\
\hline 19 & Journal of Accounting Auditing and Finance & Sage Publications & A \\
\hline 20 & Journal of Accounting Literature & Elsevier & A \\
\hline
\end{tabular}


21 Journal of Business Finance and Accounting

22 Journal of Contemporary Accounting and Economics

Journal of International Accounting Research

Journal of Management Accounting Research

The International Journal of Accounting

Accounting and the Public Interest

Accounting Education: An International Journal

Accounting Forum

Accounting Historians Journal

Accounting History and Financial History)

Accounting in Europe

Accounting Research Journal

Advances in Accounting

Advances in Accounting Behavioral Research

Advances in Management Accounting

Accounting

Asian Review of Accounting

Asia-Pacific Journal of Accounting and Economics

Australian Accounting Review

Journal of Accounting and Organizational Change

Journal of Accounting Education

Journal of Governmental \& Nonprofit Accounting Accounting Management

Pacific Accounting Review

Qualitative Research in Accounting and Management Quarterly Journal of Business and Economics)

Research in Accounting Regulation
Accounting History Review (formerly Accounting, Business

Advances in Quantitative Analysis of Finance and

International Journal of Accounting and Information Management

Taylor \& Francis Online

John Wiley \& Sons, Inc.

Journal of International Accounting, Auditing and Taxation

Journal of International Financial Management and

Journal of Public Budgeting, Accounting and Financial

Quarterly Journal of Finance and Accounting (formerly

Elsevier

Research in Governmental and Non-Profit Accounting Blsevier B

A

Elsevier A

American Accounting Association A

American Accounting Association A

Elsevier A

American Accounting Association B

Taylor \& Francis Online B

Elsevier B

The Academy of Accounting Historians B

Sage Publications B

Taylor \& Francis Online B

Taylor \& Francis Online B

Emerald Group Publishing B

Emerald Group Publishing B

Emerald Group Publishing B

Elsevier B

American Accounting Association B

Elsevier B

John Wiley \& Sons, Inc. B

PrAcademics Press, Florida B

Creighton University B

Sustainability Accounting, Management and Policy Journal

B

B

B B B $B$

B

B

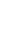

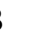
B

\section{Copyrights}

Copyright for this article is retained by the author(s), with first publication rights granted to the journal.

This is an open-access article distributed under the terms and conditions of the Creative Commons Attribution license (http://creativecommons.org/licenses/by/4.0/). 